\title{
We should do more to train anesthesia technicians in Africa
}

\author{
John Peter Oyston, MBBS
}

Received: 17 November 2014 / Accepted: 24 November 2014/Published online: 3 December 2014

(c) Canadian Anesthesiologists' Society 2014

\section{To the Editor,}

I was delighted to read the recent report by Livingston et al. promoting safe obstetrical anesthesia in Rwanda. They planned and delivered a course in a rural area, aimed at teaching and empowering the local anesthesia technicians who provide the vast majority of anesthesia care in that country. ${ }^{1}$

I have been involved in teaching anesthesiology residents under the auspices of the Canadian Anesthesiologists' Society International Education Foundation (CASIEF) in Rwanda, and with the Toronto Addis Ababa Academic Collaboration in Ethiopia under the leadership of the University of Toronto and Addis Ababa University. These programs should provide local teachers, leaders and advocates for anesthesia. However, training African physicians to become anesthesiologists will not, by itself, be enough to ensure high quality anesthesia care in Africa, for two reasons:

Firstly, once trained to international standards, the residents may become part of the African medical braindrain. Many African physicians have already emigrated to more remunerative positions in developed countries that are better able to provide the drugs, equipment and facilities they learned about in their training. For example, 5,334 physicians who were trained in subSaharan Africa now work in the USA. ${ }^{2}$

Secondly, while programs like these can train dozens of physician anesthesiologists, thousands would be needed to develop a physician-delivered anesthesia system similar to that in Canada (see Table). Countries with little money to spend on health care, a scarcity of physicians, and an even greater scarcity of physician anesthesiologists, will inevitably depend on less expensive local technicians to provide the bulk of their anesthesia care.

I heartily commend the authors for recognizing this situation and providing much needed training and support to rural anesthesia technicians in Rwanda. I am especially pleased to see that local Rwandan expertise (including anesthesiologists trained by CASIEF) is being involved. I hope that this will become a model for more widespread teaching of non-physician healthcare workers in developing countries in the future. 
Table Comparative healthcare expenditure and anesthesiology resources in Rwanda, Ethiopia, and Canada

\begin{tabular}{|c|c|c|c|}
\hline & Rwanda & Ethiopia & Canada \\
\hline Population & $11,458,000^{\mathrm{A}}$ & $91,729,000^{\mathrm{B}}$ & $34,838,000^{\mathrm{C}}$ \\
\hline $\begin{array}{l}\text { Health spending per capita } \\
\text { USD }\end{array}$ & $144^{\mathrm{A}}$ & $12^{\mathrm{B}}$ & $4,676^{\mathrm{C}}$ \\
\hline $\begin{array}{l}\text { Physicians per million } \\
\text { people }\end{array}$ & $56^{\mathrm{A}}$ & $25^{\mathrm{B}}$ & $2,068^{\mathrm{C}}$ \\
\hline Anesthesiologists & $12^{1}$ & $12^{\mathrm{D}}$ & $3,118^{\mathrm{E}}$ \\
\hline $\begin{array}{l}\text { Anesthesiologists per } \\
\text { million people }\end{array}$ & 1.0 & 0.13 & 89.5 \\
\hline $\begin{array}{l}\text { Anesthesiologists needed } \\
\text { to match Canadian ratio }\end{array}$ & 1,013 & 8,198 & - \\
\hline $\begin{array}{l}\% \text { of physicians } \\
\text { specializing in } \\
\text { anesthesiology }\end{array}$ & 1.8 & 0.5 & 4.3 \\
\hline
\end{tabular}

A World Health Organization Rwanda. Available from URL: http:// www.who.int/countries/rwa/en/ (accessed November 2014)

B World Health Organization Ethiopia. Available from URL: http:// www.who.int/countries/eth/en/ (accessed November 2014)

C World Health Organization. Canada. Available from URL: http:// www.who.int/countries/can/en/ (accessed November 2014)

D Beauvais $S$. Global Health Delivery Project at Harvard University; Tackling Anesthesia, Surgical Needs: A discussion with Ann Hau. Available from URL: http://www.globalhealthdelivery.org/blog/ 2010/11/tackling-anesthesia-surgical-needs-a-discussion-with-annhau/ (accessed November 2014)

E Canadian Medical Association. Anesthesiology Profile. Available from URL: https://www.cma.ca/Assets/assets-library/document/en/ advocacy/Anesthesiology-e.pdf (accessed November 2014)
Conflicts of interest None declared.

\section{References}

1. Livingston P, Evans F, Nsereko E, et al. Safer obstetric anesthesia through education and mentorship: a model for knowledge translation in Rwanda. Can J Anesth 2014; 61: 1028-39.

2. Hagopian A, Thompson MJ, Fordyce M, Johnson KE, Hart LG. The migration of physicians from sub-Saharan Africa to the United States of America: measures of the African brain drain. Hum Resour Health 2004; 2: 17. 